\title{
学術・技術論文
}

\section{分解運動量制御：運動量と角運動量に基づく ヒューマノイドロボットの全身運動生成}

梶 田 秀 司* 金 広 文 男* 金 子 健 二* 藤 原 清 司* 原 田 研 介* 横 井 一 仁* 比留川 博 久*

\section{Resolved Momenutm Control: Motion Generation of a Humanoid Robot based on the Linear and Angular Momenta}

\author{
Shuuji Kajita*, Fumio Kanehiro*, Kenji Kaneko*, Kiyoshi Fujiwara*, Kensuke Harada*, \\ Kazuhito Yokoi* and Hirohisa Hirukawa*
}

\begin{abstract}
We introduce a method to generate whole body motion of a humanoid robot such that the resulted total linear/angular momenta become specified values. First, we derive a linear equation which gives the total momentum of a robot from its physical parameters, the base link speed and the joint speeds. Constraints between the legs and the environment are also considered. The whole body motion is calculated from a given momentum reference by using a pseudoinverse of the inertia matrix. As examples, we generated kicking and walking motions and tested on an actual humanoid robot HRP-2. This method, the Resolved Momentum Control, gives us a unified framework to generate various maneuver of humanoid robots.
\end{abstract}

Key Words: Humanoid Robot, Biped Robot, Balance Control, Momentum Control

\section{1.はじめに}

ヒューマノイドロボットの技術を実用に供するためには，人 間と同様の様々な動作を効率よく生成する手法を確立すること が重要である. 2 足歩行はその代表的な例であり多くの研究が なされてきた [1]〜 [4]. 一方, 歩行に限定することなくバランス を維持しつつ様々な運動や作業を実現させる手法の研究が近年 活発化している。

Wooten と Hodgins は動力学シミュレーションに少数の基本 制御要素を組み合わせることにより体操競技のような複雑でダ イナミックな運動を生成できることを示した [5]. しかし，この ような行動ベースに基づく手法では制御系がロボットのモデル を持っていないために，手先を定められた点へ正確に位置決め するなどの要求に応えることが難しい.

ロボットのモデルを適切に使った, 最初の実用的なバランス動 作生成法として田宮らの研究がある [6]. 田宮らはバランス維持 を支持足で発生するモーメントを一定範囲に保持しつつ, 目標 に近い姿勢を見出す最適化問題として定式化し，提案したアル ゴリズムによりロボットを実時間でバランスさせることが可能 なことを実証した。また Baerlocher と Boulic はヒューマノイ

原稿受付 2003 年 5 月 27 日

*産業技術総合研究所

*National Institute of Advanced Industrial Science and Technology
ドロボットのようなて長多自由度系に対して，手先位置の目標 位置への制御，障害物回避，バランス制御等の複数タスクを優先 順位をつけて実現するために擬似逆行列を用いる手法を提案し ている [7]. 長阪, 稲葉, 井上 [8] や Yamane と Nakamura [9] は概略設計された動作パターンやキャプチャされた人間の運動 デー夕を各種の拘束条件や動力学的整合性を満足しヒューマノ イドロボットで実現可能なものに変換する「動力学フィル夕」あ るいは Dynamics Filter と呼ばれる手法を開発した。これらは 実用的なヒューマノイドの全身動作生成法であるが, ベースと なる運動データが必要, オフライン計算を前提とするなどの若 干の制約が存在する.

本論文ではヒューマノイドロボットの多様な運動を単純な朹 組みで生成するためロボット全体の運動量に着目する。いかに 複雑な構造を持つロボットであってもその全運動量ベクトル（並 進成分と回転成分）はロボット全体の巨視的な挙動を与えてい る.そこで逆に全運動量を陽に与えることで所望のロボットの 動作を指定できると考えられる。この計算は一見複雑に思われ るが，全運動量はロボットの構造データによって定まる慣性行 列と関節速度べクトルとの積でちえられるから，指定された全 運動量の值から必要な関節速度が逆算できる。得られた関節速 度でロボットを駆動すればバランス維持, 歩行等樣々な運動を 実現することができる，以上が本論文の基本となるアイデアで ある。

本論文の構成は以下のとおりである．第 2 章ではロボットの 
運動量に関する基礎的な方程式と，空間的な拘束の影響につい て考察する。これを用いて第 3 章で与えられた全運動量を実現 する関節運動を計算する動作生成手法「分解運動量制御」を定 式化する．第 4 章では分解運動量制御の実装に必要な絶対空間 での慣性行列の再帰計算法について説明する，第 5 章では実際 のヒューマノイドロボットを用いてキック動作と歩行動作の実 験を行い，機能を評価する，第 6 章で本論文のまとめと今後の 展望について述べる。

\section{2. 運動量方程式}

\section{1 関節角速度と全運動量の関係}

$n$ 個の能動関節を持つヒューマノイドロボットを空間内 6 自 由度を持つボディリンク（腰リンク）とこれに接続された開り ンク機構でモデル化する（Fig. 1)．ボディに位置と姿勢が一致 する座標系 $\Sigma_{B}$ で表現されたボディの並進速度と角速度を $\boldsymbol{v}_{B}$, $\boldsymbol{\omega}_{B}$ ，ロボットの全関節速度を縦に並べた $n \times 1$ ベクトルを $\dot{\boldsymbol{\theta}}$ とする．ロボット全体の並進運動量 $\boldsymbol{P}(3 \times 1)$ と重心回りの角 運動量 $\boldsymbol{L}(3 \times 1)$ は次式で与えられる.

$$
\left[\begin{array}{c}
\boldsymbol{P} \\
\boldsymbol{L}
\end{array}\right]=\left[\begin{array}{ccc}
\tilde{m} \boldsymbol{E} & -\tilde{m} \hat{\boldsymbol{r}}_{B \rightarrow \tilde{c}} & \boldsymbol{M}_{\dot{\theta}} \\
\mathbf{0} & \tilde{\boldsymbol{I}} & \boldsymbol{H}_{\dot{\theta}}
\end{array}\right]\left[\begin{array}{c}
\boldsymbol{v}_{B} \\
\boldsymbol{\omega}_{B} \\
\dot{\boldsymbol{\theta}}
\end{array}\right]
$$

ここで $\tilde{m}$ はロボットの全質量, $\boldsymbol{E}$ は $3 \times 3$ の単位行列, $\boldsymbol{r}_{B \rightarrow \tilde{c}}$ は腰リンクから全重心 $\tilde{\boldsymbol{c}}$ への位置ベクトル $(3 \times 1), \tilde{\boldsymbol{I}}$ は全重心 回りの慣性行列 $(3 \times 3) . \boldsymbol{M}_{\dot{\theta}}, \boldsymbol{H}_{\dot{\theta}}$ は関節速度がそれぞれ並進 運動量と角運動量に及ほす効果を表す慣性行列である $(3 \times n)$. また, 記号へは $3 \times 1$ のベクトルを外積と等価な $3 \times 3$ の歪対 称行列に変換する操作を表す。式を簡単化し見通しをよくする ため本論文における位置, 速度, 角速度べクトルおよびそれに 関連するヤコビアン等はすべて地面座標系 $\Sigma_{O}$ で考える，座標 軸はロボットの前, 左, 上をそれぞれ $x, y, z$ とする.

\section{2 脚に関する拘束条件}

式 (1) は $n+6$ 個の速度変数から運動量への変換式を与える が, 実際の歩行ロボットでは床面との相互作用によって系の自 由度が減少する. 今, 両脚先端 $\Sigma_{F_{i}}(i=1,2)$ の速度 $\boldsymbol{v}_{F_{i}}$, 角

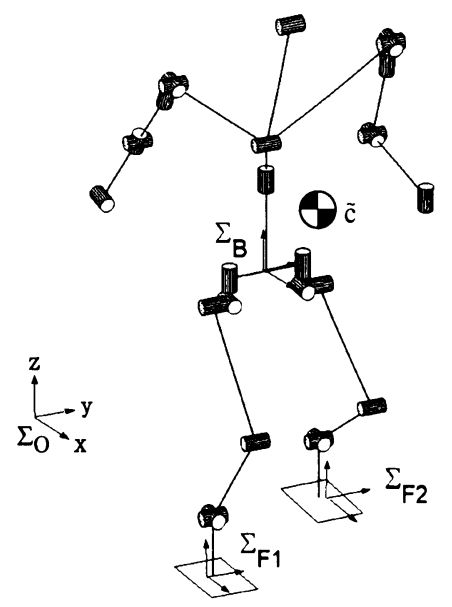

Fig. 1 A model of humanoid robot
速度 $\boldsymbol{\omega}_{F_{i}}$ が与えられたとすると次式が成り立つ。

$$
\left[\begin{array}{c}
\boldsymbol{v}_{F_{i}} \\
\boldsymbol{\omega}_{F_{i}}
\end{array}\right]=\left[\begin{array}{cc}
\boldsymbol{E} & -\hat{\boldsymbol{r}}_{B \rightarrow F_{i}} \\
\mathbf{0} & \boldsymbol{E}
\end{array}\right]\left[\begin{array}{c}
\boldsymbol{v}_{B} \\
\boldsymbol{\omega}_{B}
\end{array}\right]+\boldsymbol{J}_{\text {leg }_{i}} \dot{\boldsymbol{\theta}}_{\text {leg }_{i}},
$$

$\boldsymbol{J}_{\text {leg }_{i}}$ は脚の構造と姿勢から定まるヤコビアン $(6 \times 6), \boldsymbol{r}_{B \rightarrow F_{i}}$ はボディリンク原点から脚先端へ向かう位置ベクトル, $\dot{\boldsymbol{\theta}}_{\text {leg }_{i}}(i=$ $1,2)$ はそれぞれの脚の関節速度ベクトル $(6 \times 1)$ である. 式 $(2)$ より脚が特異姿勢でなければ $\dot{\boldsymbol{\theta}}_{\text {leg }_{i}}$ は次式で与えられる.

$$
\dot{\boldsymbol{\theta}}_{\text {leg }_{i}}=\boldsymbol{J}_{\text {leg }_{i}}^{-1}\left[\begin{array}{c}
\boldsymbol{v}_{F_{i}} \\
\boldsymbol{\omega}_{F_{i}}
\end{array}\right]-\boldsymbol{J}_{\text {leg }_{i}}^{-1}\left[\begin{array}{cc}
\boldsymbol{E} & -\hat{\boldsymbol{r}}_{B \rightarrow F_{i}} \\
\mathbf{0} & \boldsymbol{E}
\end{array}\right]\left[\begin{array}{c}
\boldsymbol{v}_{B} \\
\boldsymbol{\omega}_{B}
\end{array}\right] .
$$

\section{3 拘束条件を考慮した運動量方程式}

拘束条件を付加した場合の運動量を計算するために, 関節速 度ベクトルを左右の脚に関する $\dot{\boldsymbol{\theta}}_{\operatorname{leg}_{1}}, \dot{\boldsymbol{\theta}}_{\mathrm{leg}_{2}}$ とそれ以外の部分 $\dot{\boldsymbol{\theta}}_{\text {free }}$ に分解しよう. 対応する慣性行列も同様に分割する.

$$
\begin{aligned}
\dot{\boldsymbol{\theta}} & =\left[\begin{array}{lll}
\dot{\boldsymbol{\theta}}_{\text {leg }_{1}}^{T} & \dot{\boldsymbol{\theta}}_{\text {leg }_{2}}^{T} & \dot{\boldsymbol{\theta}}_{\text {free }}^{T}
\end{array}\right]^{T} \\
\boldsymbol{M}_{\dot{\theta}} & =\left[\begin{array}{lll}
\boldsymbol{M}_{\text {leg }_{1}} & \boldsymbol{M}_{\text {leg }_{2}} & \boldsymbol{M}_{\text {free }}
\end{array}\right] \\
\boldsymbol{H}_{\dot{\theta}} & =\left[\begin{array}{lll}
\boldsymbol{H}_{\text {leg }_{1}} & \boldsymbol{H}_{\text {leg }_{2}} & \boldsymbol{H}_{\text {free }}
\end{array}\right]
\end{aligned}
$$

これらを用いて運動量方程式（1）を書き直すと，

$$
\begin{aligned}
{\left[\begin{array}{l}
\boldsymbol{P} \\
\boldsymbol{L}
\end{array}\right]=} & {\left[\begin{array}{cc}
\tilde{m} \boldsymbol{E} & -\tilde{m} \hat{\boldsymbol{r}}_{B \rightarrow \tilde{c}} \\
\mathbf{0} & \tilde{\boldsymbol{I}}
\end{array}\right]\left[\begin{array}{c}
\boldsymbol{v}_{B} \\
\boldsymbol{\omega}_{B}
\end{array}\right] } \\
& +\sum_{i=1}^{2}\left[\begin{array}{c}
\boldsymbol{M}_{\text {leg }_{i}} \\
\boldsymbol{H}_{\text {leg }_{i}}
\end{array}\right] \dot{\boldsymbol{\theta}}_{\text {leg }_{i}}+\left[\begin{array}{c}
\boldsymbol{M}_{\text {free }} \\
\boldsymbol{H}_{\text {free }}
\end{array}\right] \dot{\boldsymbol{\theta}}_{\text {free }} .
\end{aligned}
$$

式（3）を式（4）に代入することで, 拘束条件下の運動量方程 式を得る.

$$
\begin{aligned}
{\left[\begin{array}{c}
\boldsymbol{P} \\
\boldsymbol{L}
\end{array}\right]=} & {\left[\begin{array}{cc}
\tilde{m} \boldsymbol{E} & -\tilde{m} \hat{\boldsymbol{r}}_{B \rightarrow \tilde{c}} \\
\mathbf{0} & \tilde{\boldsymbol{I}}
\end{array}\right] \boldsymbol{\xi}_{B} } \\
& +\sum_{i=1}^{2}\left[\begin{array}{c}
\boldsymbol{M}_{\text {leg }_{i}} \\
\boldsymbol{H}_{\text {leg }_{i}}
\end{array}\right] \boldsymbol{J}_{\operatorname{leg}_{i}}^{-1}\left(\boldsymbol{\xi}_{F_{i}}-\left[\begin{array}{cc}
\boldsymbol{E} & -\hat{\boldsymbol{r}}_{B \rightarrow F_{i}} \\
\mathbf{0} & \boldsymbol{E}
\end{array}\right] \boldsymbol{\xi}_{B}\right) \\
& +\left[\begin{array}{c}
\boldsymbol{M}_{\text {free }} \\
\boldsymbol{H}_{\text {free }}
\end{array}\right] \dot{\boldsymbol{\theta}}_{\text {free. }} .
\end{aligned}
$$

ここで速度，角速度べクトルを以下のようにまとめた。

$$
\boldsymbol{\xi}_{B} \equiv\left[\begin{array}{c}
\boldsymbol{v}_{B} \\
\boldsymbol{\omega}_{B}
\end{array}\right], \quad \boldsymbol{\xi}_{F_{i}} \equiv\left[\begin{array}{c}
\boldsymbol{v}_{F_{i}} \\
\boldsymbol{\omega}_{F_{i}}
\end{array}\right] .
$$

式（5）を整理することにより，脚の拘束条件を考虑したロ ボットの速度と運動量の関係式が次のような簡潔な形で与えら れる。

$$
\left[\begin{array}{c}
\boldsymbol{P} \\
\boldsymbol{L}
\end{array}\right]=\left[\begin{array}{cc}
\boldsymbol{M}_{B}^{*} & \boldsymbol{M}_{\text {free }} \\
\boldsymbol{H}_{B}^{*} & \boldsymbol{H}_{\text {free }}
\end{array}\right]\left[\begin{array}{c}
\boldsymbol{\xi}_{B} \\
\dot{\boldsymbol{\theta}}_{\text {free }}
\end{array}\right]+\sum_{i=1}^{2}\left[\begin{array}{c}
\boldsymbol{M}_{F_{i}}^{*} \\
\boldsymbol{H}_{F_{i}}^{*}
\end{array}\right] \boldsymbol{\xi}_{F_{i}},
$$


清司原田研介横井一仁比留川博久

ここで, $\boldsymbol{M}_{B}^{*}, \boldsymbol{H}_{B}^{*}, \boldsymbol{M}_{F_{i}}^{*}, \boldsymbol{H}_{F_{i}}^{*}$ は拘束条件を考慮した慣性行列 を表し，次式により与えられる。

$$
\begin{aligned}
{\left[\begin{array}{c}
\boldsymbol{M}_{B}^{*} \\
\boldsymbol{H}_{B}^{*}
\end{array}\right] \equiv } & {\left[\begin{array}{cc}
\tilde{m} \boldsymbol{E} & -\tilde{m} \hat{\boldsymbol{r}}_{B \rightarrow \tilde{c}} \\
\mathbf{0} & \tilde{\boldsymbol{I}}
\end{array}\right] } \\
& -\sum_{i=1}^{2}\left[\begin{array}{c}
\boldsymbol{M}_{F_{i}}^{*} \\
\boldsymbol{H}_{F_{i}}^{*}
\end{array}\right]\left[\begin{array}{cc}
\boldsymbol{E} & -\hat{\boldsymbol{r}}_{B \rightarrow F_{i}} \\
\mathbf{0} & \boldsymbol{E}
\end{array}\right], \\
{\left[\begin{array}{c}
\boldsymbol{M}_{F_{i}}^{*} \\
\boldsymbol{H}_{F_{i}}^{*}
\end{array}\right] \equiv } & {\left[\begin{array}{c}
\boldsymbol{M}_{\text {leg }_{i}} \\
\boldsymbol{H}_{\text {leg }_{i}}
\end{array}\right] \boldsymbol{J}_{\text {leg }_{i}}^{-1} . }
\end{aligned}
$$

\section{3. 分解運動量制御}

\section{1 目標運動量の設定}

どのように複雑な構造を持つ多リンク機構であっても運動中 の各瞬間において重心位置 $\tilde{\boldsymbol{c}}$, 全並進運動量 $\boldsymbol{P}$, 全角運動量 $\boldsymbol{L}$ の各 $x, y, z 3$ 成分, 計 9 個の状態量を決定できる.

また，全並進運動量 $\boldsymbol{P}$ を全質量 $\tilde{m}$ で割ったものは重心の並 進速度に一致することに注意しよう。

$$
\frac{d}{d t} \tilde{\boldsymbol{c}}=\frac{\boldsymbol{P}}{\tilde{m}}
$$

すなわち, 重心運動は並進運動量の積分值で与えられるから，結 局 $\boldsymbol{P}, \boldsymbol{L}$ の 6 個の状態量を逐次与えていくことでロボットの大 局的な運動を決定できることになる。

このようにロボットの全運動量を陽に指定し，これを満足す るように関節を駆動する軌道生成/制御方式を「分解運動量制 御（Resolved Momentum Control）」と呼ぶことにする 。こ れは多リンク系であるヒューマノイドロボットを質量が等しく 可変な慣性モーメントを持つ仮想的な一個の剛体とみなして制 御することを意味する。両者の重心位置, 重心速度, 角運動量は 原理的に完全に一致させることができるが，角運動量を与えた 結果として得られる仮想的な剛体の姿勢を現実のロボットの姿 勢に関連付けることはできない，例えば多りンク系の場合，角 運動量が 0 であっても姿勢が変化するいわゆる「猫ひねり」の ような動作が可能であるが，この現象は分解運動量制御のゼロ 空間において生じるため, 単一の剛体運動では表現することが できない.

\section{2 運動量の選択と擬似逆行列による制御}

分解運動量制御は全運動量の目標値 $\boldsymbol{P}^{r e f}, \boldsymbol{L}^{r e f}$ と各脚先端の 目標速度 $\boldsymbol{\xi}_{F_{i}}^{r e f}$ を与え, これを実現する腰速度と関節速度べクト ルを計算する軌道生成法である，ところが後で述べるように，運 動量のすべての成分を実現しようとするとロボットの挙動がむ しろ不自然になる場合があるため (5.1 節)，制御したい運動量 成分を次のような $l \times 6$ の選択行列 $S$ で抽出する $(0<l \leq 6)$.

$$
\boldsymbol{S} \equiv\left[\begin{array}{c}
\boldsymbol{e}_{s_{1}}^{T} \\
\vdots \\
\boldsymbol{e}_{s_{l}}^{T}
\end{array}\right]
$$

$\boldsymbol{e}_{s_{i}}$ は全運動量ベクトルの第 $s_{i}$ 成分に対応する要素を 1 , それ

†本研究の初期段階では「分解運動量制御」を「モーメンタム・コント ロール」と呼んでいた [10].
以外を 0 とした $6 \times 1$ の列ベクトルである. 例えば並進運動量 の $x$ 成分と角運動量の $y, z$ 成分を制御し，他の成分について 関知しないのであれば, $S=\left[\boldsymbol{e}_{1} \boldsymbol{e}_{5} \boldsymbol{e}_{6}\right]^{T}$ のように設定する.

第 2 章で求めた運動量方程式（6）の右辺第二項を左辺へ移 項した後, 左から $\boldsymbol{S}$ を乗じ, 次式を得る.

$$
\boldsymbol{y}=\boldsymbol{A}\left[\begin{array}{c}
\boldsymbol{\xi}_{B} \\
\dot{\boldsymbol{\theta}}_{\text {free }}
\end{array}\right]
$$

ここで,

$$
\begin{aligned}
& \boldsymbol{y} \equiv \boldsymbol{S}\left\{\left[\begin{array}{l}
\boldsymbol{P}^{r e f} \\
\boldsymbol{L}^{r e f}
\end{array}\right]-\sum_{i=1}^{2}\left[\begin{array}{c}
\boldsymbol{M}_{F_{i}}^{*} \\
\boldsymbol{H}_{F_{i}}^{*}
\end{array}\right] \boldsymbol{\xi}_{F_{i}}^{r e f}\right\}, \\
& \boldsymbol{A} \equiv \boldsymbol{S}\left[\begin{array}{ll}
\boldsymbol{M}_{B}^{*} & \boldsymbol{M}_{\text {free }} \\
\boldsymbol{H}_{B}^{*} & \boldsymbol{H}_{\text {free }}
\end{array}\right] .
\end{aligned}
$$

式（9）により，目標運動量 $\boldsymbol{P}^{r e f} ， \boldsymbol{L}^{r e f}$ の選択された成分と目 標足先速度 $\boldsymbol{\xi}_{F_{i}}^{r e f}$ を二乗ノルム最小の意味で実現するベースリン クおよび脚以外の関節速度は次式で与えられる。

$$
\left[\begin{array}{c}
\boldsymbol{\xi}_{B} \\
\dot{\boldsymbol{\theta}}_{\text {free }}
\end{array}\right]=\boldsymbol{A}^{\dagger} \boldsymbol{y}+\left(\boldsymbol{E}-\boldsymbol{A}^{\dagger} \boldsymbol{A}\right)\left[\begin{array}{c}
\boldsymbol{\xi}_{B}^{\text {ref }} \\
\dot{\boldsymbol{\theta}}_{\text {free }}^{\text {ref }}
\end{array}\right],
$$

ここで $\boldsymbol{A}^{\dagger}$ は $\boldsymbol{A}$ の擬似逆行列を表す. $\boldsymbol{\xi}_{B}^{r e f}$ はベースリンクの 参照速度, $\dot{\boldsymbol{\theta}}_{\text {free }}^{\text {ref }}$ は脚以外の関節の参照速度であり, 目標運動量 を作り出すのに矛盾しない範囲で実現される，上式で得られた ベースリンクの速度 $\boldsymbol{\xi}_{B}$ を用いで次式により脚の関節速度を計 算する（式（3）に同じ）。

$$
\dot{\boldsymbol{\theta}}_{\operatorname{leg}_{i}}=\boldsymbol{J}_{\operatorname{leg}_{i}}^{-1}\left(\boldsymbol{\xi}_{F_{i}}^{r e f}-\left[\begin{array}{cc}
\boldsymbol{E} & -\hat{\boldsymbol{r}}_{B \rightarrow F_{i}} \\
\mathbf{0} & \boldsymbol{E}
\end{array}\right] \boldsymbol{\xi}_{B}\right) .
$$

以上をまとめると分解運動量制御では次の手順で軌道を計算 することになる．

Step 1 制御したい運動量成分に応じて選択行列 $\boldsymbol{S}$ を設 定する.

Step 2 現時刻に扔ける関節角度 $\boldsymbol{\theta}$, ベースリンクの位 置 $\boldsymbol{p}_{B}$, 姿勢 $\boldsymbol{R}_{B}$ より，式（11）により行列 $\boldsymbol{A}$ を計 算する.

Step 3 目標全運動量 $\boldsymbol{P}^{r e f}, \boldsymbol{L}^{r e f}$ および，目標足先速度 $\boldsymbol{\xi}_{F_{i}}^{r e f}$ を設定し，式 (10)によりべクトル $\boldsymbol{y}$ を計算する.

Step 4 式（12）によりべースリンク速度 $\boldsymbol{\xi}_{B}$ および, 脚 以外の関節速度 $\dot{\boldsymbol{\theta}}_{\text {free }}$ を計算する。

Step 5 ベースリンク速度 $\boldsymbol{\xi}_{B}$ と目標足先速度 $\boldsymbol{\xi}_{F_{i}}^{r e f}$ より 式（13）により脚関節速度 $\dot{\boldsymbol{\theta}}_{\text {leg }_{i}}$ を計算する.

Step 6 関節速度 $\dot{\theta}=\left[\dot{\theta}_{\text {leg }_{1}}^{T} \dot{\theta}_{\text {leg }_{2}}^{T} \dot{\theta}_{\text {free }}^{T}\right]^{T}$ を積分して次 の時刻における関節角度 $\boldsymbol{\theta}$ を求める。ベースリンク 速度 $\boldsymbol{\xi}_{B}$ を積分して次の時刻における位置 $\boldsymbol{p}_{B}$, 姿勢 $\boldsymbol{R}_{B}$ を求める。

Step 7 Step 2 へ戻る. 


\section{3 関連する研究について}

角運動量を状態量としてロボットの動作設計やフィードバック 制御に利用することは佐野と古荘の三次元動的 2 足歩行制御 [11] を先駆とし，水戸部らのバランス制御 $[12]$ ，筆者らのバランス 制御 [13]，池田らによる走行ロボットの制御 [14] など多くの研 究において行われてきた。一方，杉原らはロボット全体の重心 位置を直接操作することで軌道生成や制御を行う方式を提案し ている [15].これは並進運動量の制御に等しく，特に式（6）に 現れる慣性行列の上半分 $\left[\boldsymbol{M}_{B}^{*} \boldsymbol{M}_{\text {free }}\right]$ を全質量 $\tilde{m}$ で割ったも のは「重心ヤコビアン」を与える.

また，宇宙ロボットの分野では従来より運動量の重要性が指 摘されてきた，梅谷と吉田は運動量保存則を包含した分解速度 制御法を提案し，これにより浮遊ベース上に設置されたマニピュ レー夕先端を絶対座標系で正確に制御できることを示した [16]. これと等価な計算を分解運動量制御を用いて以下のように行う ことができる．先に定義した記号を流用するため宇宙ロボット を軌道上に浮遊する 1 本足の脚ロボットと考えよう。適切な座 標系を設定すれば目標運動量を $\boldsymbol{P}^{r e f}=\mathbf{0}, \boldsymbol{L}^{r e f}=\mathbf{0}$ とできる. 選択行列 $\boldsymbol{S}=\boldsymbol{E}$ とすると式（10）は,

$$
\boldsymbol{y}=\left\{\left[\begin{array}{l}
\mathbf{0} \\
\mathbf{0}
\end{array}\right]-\left[\begin{array}{c}
\boldsymbol{M}_{F_{1}}^{*} \\
\boldsymbol{H}_{F_{1}}^{*}
\end{array}\right] \boldsymbol{\xi}_{F_{1}}^{r e f}\right\} .
$$

ここで, $\boldsymbol{\xi}_{F_{1}}^{r e f}$ が目標とする足先速度 (手先速度) である. ロボッ トがベースリンクと 1 本の脚のみで構成されている場合 $\boldsymbol{A}$ は $6 \times 6$ の正方行列となるから, 式 (12) は,

$$
\boldsymbol{\xi}_{B}=\boldsymbol{A}^{-1} \boldsymbol{y}
$$

$\boldsymbol{\xi}_{B}$ は脚の反動で生ずるベースリンクの速度である. 最後に式 （13）を使って, 希望する連動を作り出す脚関節速度が計算さ れる。

$$
\dot{\boldsymbol{\theta}}_{\text {leg }_{1}}=\boldsymbol{J}_{\operatorname{leg}_{1}}^{-1}\left(\boldsymbol{\xi}_{F_{1}}^{r e f}-\left[\begin{array}{cc}
\boldsymbol{E} & -\hat{\boldsymbol{r}}_{B \rightarrow F_{1}} \\
\mathbf{0} & \boldsymbol{E}
\end{array}\right] \boldsymbol{\xi}_{B}\right)
$$

以上のように分解運動量制御はロボットの運動計画や制御の ために従来提案されてきた様々な方式を包含する概念であると 考えられる。

\section{4. 慣性行列の計算}

本章では式（1）における慣性行列 $\boldsymbol{M}_{\dot{\theta}}$ と $\boldsymbol{H}_{\dot{\theta}}$ を算出する方 法を説明する. Fig. 2 はヒューマノイドロボットの一部を構成 する隣接したリンクと関節 $j-1$ 軸と $j$ 軸を示す。各関節は適 切な制御により指定された回転速度を発生できるとしよう。第 $j$ 関節が角速度 $\dot{\theta}_{j}$ で回転することにより新たに発生する並進 運動量と角運動量は次式で与えられる。

$$
\begin{aligned}
\boldsymbol{P}_{j} & =\boldsymbol{\omega}_{j} \times\left(\tilde{\boldsymbol{c}}_{j}-\boldsymbol{r}_{j}\right) \tilde{m}_{j}, \\
\boldsymbol{L}_{j} & =\tilde{\boldsymbol{c}}_{j} \times \boldsymbol{P}_{j}+\tilde{\boldsymbol{I}}_{j} \boldsymbol{\omega}_{j}, \\
\boldsymbol{\omega}_{j} & \equiv \boldsymbol{a}_{j} \dot{\theta}_{j},
\end{aligned}
$$

$\boldsymbol{r}_{j}$ と $\boldsymbol{a}_{j}$ は関節 $j$ の位置べクトルと回転軸べクトルを示す。ま た, $\tilde{m}_{j}, \tilde{\boldsymbol{c}}_{j}, \tilde{\boldsymbol{I}}_{j}$ は関節 $j よ り$ 先端に存在する全りンクの質

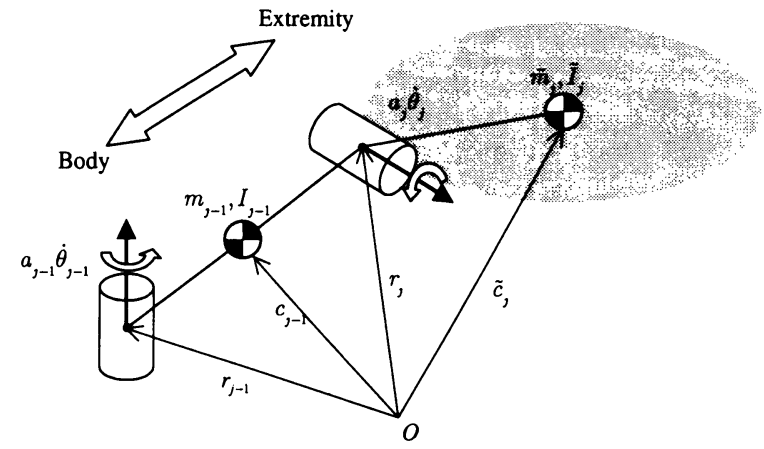

Fig. 2 Link configulation

量，重心位置，慣性テンソルを合算したものである．

関節 $j$ に対応する慣性行列の並進運動成分と回転運動成分は それぞれ次式で与えられる。

$$
\begin{array}{r}
\boldsymbol{m}_{j} \equiv \boldsymbol{P}_{j} / \dot{\theta}_{j}, \\
\boldsymbol{h}_{j} \equiv \boldsymbol{L}_{j} / \dot{\theta}_{j},
\end{array}
$$

$\boldsymbol{m}_{j}, \boldsymbol{h}_{j}$ はそれぞれ $3 \times 1$ のベクトルである. 式（14）と式 （17）を比較することで $\boldsymbol{m}_{j}$ が，式（15）と式（18）を比較す ることで $\boldsymbol{h}_{j}$ が得られる。

$$
\begin{aligned}
\boldsymbol{m}_{j} & =\boldsymbol{a}_{j} \times\left(\tilde{\boldsymbol{c}}_{j}-\boldsymbol{r}_{j}\right) \tilde{m}_{j}, \\
\boldsymbol{h}_{j} & =\tilde{\boldsymbol{c}}_{j} \times \boldsymbol{m}_{j}+\tilde{\boldsymbol{I}}_{j} \boldsymbol{a}_{j} .
\end{aligned}
$$

これらを用いて慣性行列 $\boldsymbol{M}_{\dot{\theta}}, \boldsymbol{H}_{\dot{\theta}}$ は以下のように構成される.

$$
\begin{aligned}
\boldsymbol{M}_{\dot{\theta}} & =\left[\boldsymbol{m}_{1}, \boldsymbol{m}_{2}, \ldots \boldsymbol{m}_{n}\right], \\
\boldsymbol{H}_{\dot{\theta}} & ={ }^{0} \boldsymbol{H}_{\dot{\theta}}-\widehat{\tilde{\boldsymbol{c}}} \boldsymbol{M}_{\dot{\theta}}, \\
{ }^{0} \boldsymbol{H}_{\dot{\theta}} & \equiv\left[\boldsymbol{h}_{1}, \boldsymbol{h}_{2}, \ldots \boldsymbol{h}_{n}\right] .
\end{aligned}
$$

式（22）は地面座標系原点回りの角運動量を重心回りの角運動 量に変換している.

$\tilde{m}_{j}, \tilde{\boldsymbol{c}}_{j}, \tilde{\boldsymbol{I}}_{j}$ はリンク先端より再帰的に計算して求めること ができる. 今, 関節 $j よ り$ 先端の質量 $\tilde{m}_{j}$, 重心位置 $\tilde{\boldsymbol{c}}_{j}$, 慣性 テンソル $\tilde{\boldsymbol{I}}_{j}$ が既に得られているとすると, それより一つ胴体 よりの関節 $j-1$ に関しては

$$
\begin{aligned}
\tilde{m}_{j-1}= & \tilde{m}_{j}+m_{j-1} \\
\tilde{\boldsymbol{c}}_{j-1}= & \left(\tilde{m}_{j} \tilde{\boldsymbol{c}}_{j}+m_{j-1} \boldsymbol{c}_{j-1}\right) /\left(\tilde{m}_{j}+m_{j-1}\right) \\
\tilde{\boldsymbol{I}}_{j-1}= & \tilde{\boldsymbol{I}}_{j}+\tilde{m}_{j} \boldsymbol{D}\left(\tilde{\boldsymbol{c}}_{j}-\tilde{\boldsymbol{c}}_{j-1}\right)+\boldsymbol{R}_{j-1} \boldsymbol{I}_{j-1} \boldsymbol{R}_{j-1}^{T} \\
& +m_{j-1} \boldsymbol{D}\left(\boldsymbol{c}_{j-1}-\tilde{\boldsymbol{c}}_{j-1}\right) \\
\boldsymbol{D}(\boldsymbol{r}) \equiv & \hat{\boldsymbol{r}}^{T} \hat{\boldsymbol{r}}
\end{aligned}
$$

$m_{j-1}, \boldsymbol{c}_{j-1}, \boldsymbol{R}_{j-1}$ は第 $j-1$ リンクの質量, 重心位置, 姿勢 行列を表す。また $\boldsymbol{I}_{j-1}$ は各リンクのローカル座標系で表され た慣性テンソルである。

\section{5. 運動生成例}

ここでは, 実際のヒューマノイドロボット HRP-2によるシミュ レーションと実験により分解運動量制御を評価する．HRP-2 は 経済産業省の人間協調・共存型ロボットプロジェクト (HRP) [17] 

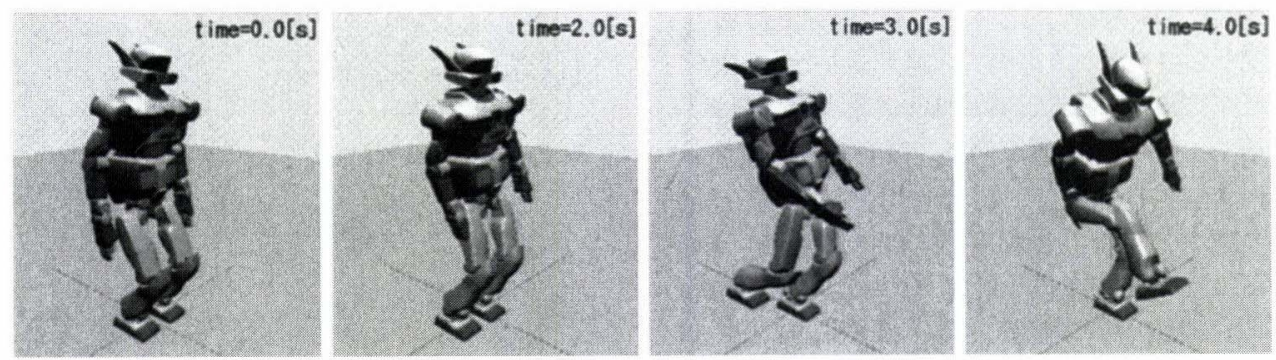

Fig. 3 Kick: $S=E$
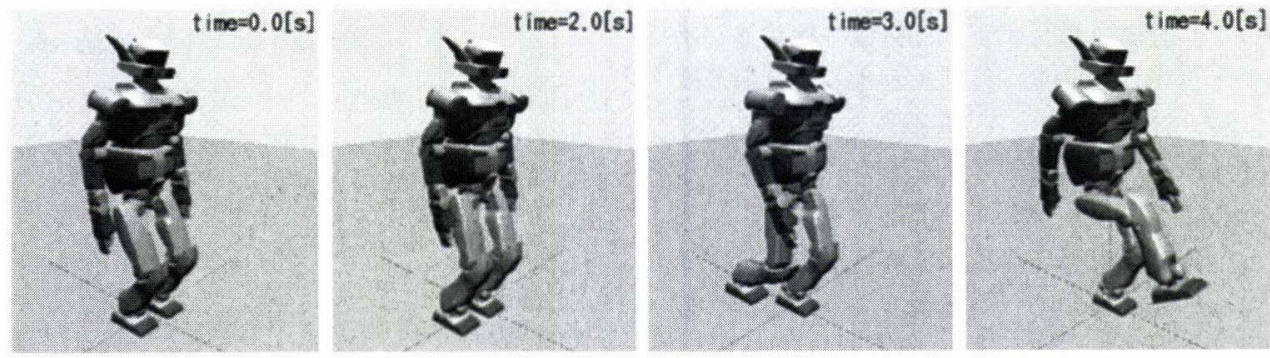

Fig. 4 Kick: $S=\left[\boldsymbol{e}_{1} \boldsymbol{e}_{2} \boldsymbol{e}_{3} \boldsymbol{e}_{6}\right]^{T}$

において開発された身長 $154[\mathrm{~cm}]$, 体重 $58[\mathrm{~kg}]$, 全 30 自由度 のロボットであり，腰にヨー，ピッチの 2 軸，股関節に片持ち 構造を持つなどの特徴を持っている [18].

\section{1 キック動作}

Fig. 3，4 は, バランスを保持しつつキック動作を行った計 算結果を示す. 両脚支持から片脚支持へ移行し，以後重心を支 持脚直上に維持するため目標運動量を次式で与えた。

$$
\begin{aligned}
& P_{x, y}^{r e f}=\tilde{m} K_{p}\left(\tilde{c}_{x, y}^{r e f}-\tilde{c}_{x, y}\right)+\dot{\tilde{c}}_{x, y}^{\text {ref }}, \\
& P_{z}^{r e f}=\tilde{m} K_{p}\left(z_{B}^{r e f}-z_{B}\right), \\
& \boldsymbol{L}^{\text {ref }}=\mathbf{0} .
\end{aligned}
$$

$K_{p}$ は適当なフィードバックゲインでヤコビアンの時間微分に 起因する誤差を補正するために与える。 $\tilde{\boldsymbol{c}}^{r e f}$ は重心の目標位置, $\dot{\tilde{c}}^{r e f}$ は目標重心速度, $z_{B}$ は目標の腰高さである。キック動作 や次節の歩行動作では全重心高さを一定とするよりも腰高さ一 定のほうが好都合なため, 式 (29) によって $z$ 方向の並進運動 量経由で腰高さを制御している。

キック動作を生成するために右足に与えた目標速度 $\boldsymbol{\xi}_{F_{1}}^{r e f}$ のパ ターンをFig. 5 に示す．左足は地面に着地したままなので全期 間において $\boldsymbol{\xi}_{F_{2}}^{r e f}=0$ である. 以上の目標運動量と目標速度パ ターンを用い 3 章で示したアルゴリズムに従ってロボットの運 動を計算した。離散化時間は $5[\mathrm{~ms}]$ とした。

Fig. 3 では式（8）の選択行列 $\boldsymbol{S}$ を単位行列として, 目標運 動量の全成分が実現されるように運動を生成した。ロボットは 両脚支持の初期姿勢から重心を左脚の上へ移動させ $(0.0[\mathrm{~s}] \rightarrow$ $2.0[\mathrm{~s}])$, 右脚を持ち上げて後方へ引き $(2.0[\mathrm{~s}] \rightarrow 3.0[\mathrm{~s}])$, 前方 へキックする $(3.0[\mathrm{~s}] \rightarrow 4.0[\mathrm{~s}])$. Fig. 6 は生成された運動パ ターンから改めて全運動量を計算し, 設定した目標運動量が再 現されていることを確認したものである．上段のグラフは並進 運動量を示し，ロボットが片脚でバランスを維持している $2.0[\mathrm{~s}]$ から $4.5[\mathrm{~s}]$ にかけて $P_{x}, P_{y}$ がほぼ 0 に保たれていることが分
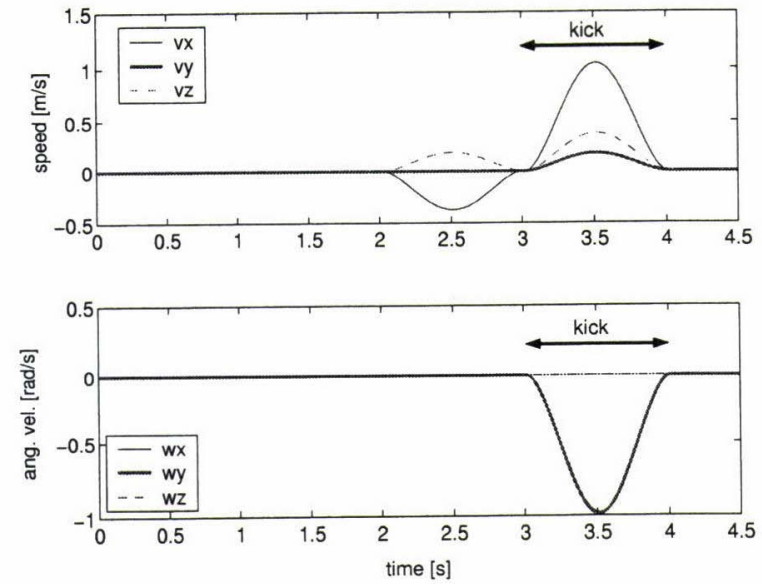

Fig. 5 Reference velocity of right foot $\boldsymbol{\xi}_{F_{1}}^{\text {ref }}$

かる. $P_{z}$ は式 $(29)$ によって腰高さを一定にするため変動して いる。 な扔, $0.0[\mathrm{~s}]$ から $2.0[\mathrm{~s}]$ にかけて $P_{y}$ が大きく増減して いるのはロボットの重心が左脚真上に移動したことによる.

Fig. 6 下段のグラフはロボットの重心回りの角運動量 $\boldsymbol{L}$ が式 （30）で指定されたとおり0 を維持していることを示している (厳密には離散化に伴う誤差によって $\pm 0.03[\mathrm{Nms}]$ 程度の変動 が存在する). Fig. 3 の time $=3.0,4.0[\mathrm{~s}]$ の図に見られるよう にロボットは重心回りの全角運動量を 0 に保つため脚を後方に 引く際には胴体を反り返らせ，前へ振り出す際には胴体を前に 屈めるような動作を行っている。この結果，股関節に掞ける関 節可動範囲の超過と腕と胴体の干渉が発生するため実現不可能 なパ夕ーンになっている.

角運動量の全成分を目標値どおり制御しようとして発生する 上述の問題を解消するために, 選択行列を $S=\left[e_{1} e_{2} e_{3} e_{6}\right]^{T}$ として角運動量のうち $L_{x}, L_{y}$ の制御を行わないように設定し た場合の結果を Fig. 4 に示す。角運動量の制御を一部断念した 

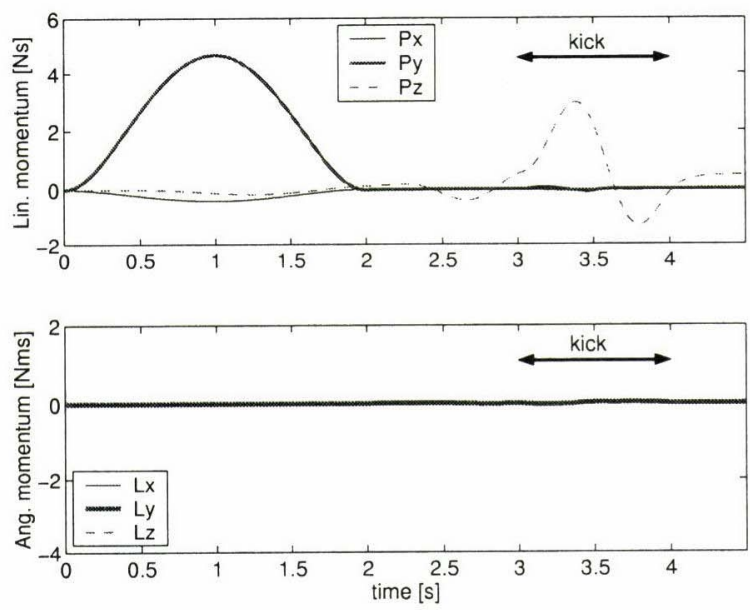

Fig. 6 Momentum change during kick action $(S=E)$
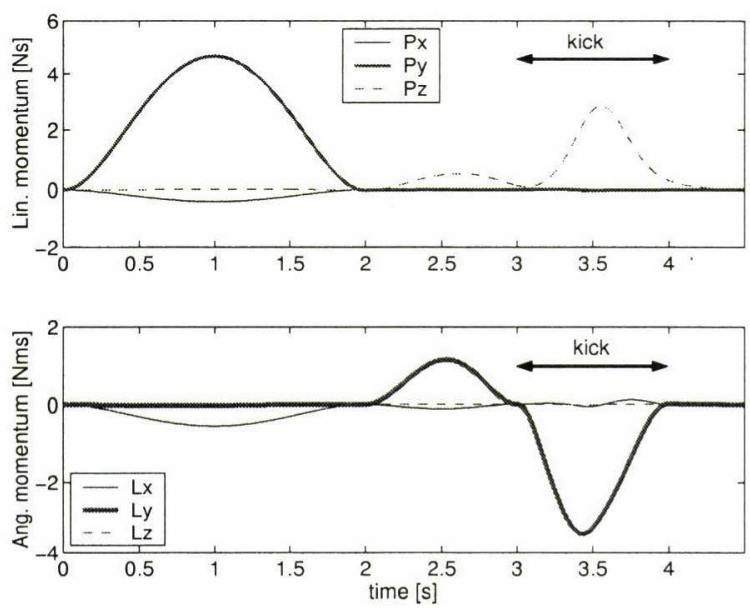

Fig. 7 Momentum change during kick action $\left(S=\left[\boldsymbol{e}_{1} \boldsymbol{e}_{2} \boldsymbol{e}_{3} \boldsymbol{e}_{6}\right]^{T}\right)$

結果，胴体を鉛直に保つ無理のないキック動作が生成されてい る.Fig. 7 がその運動量であり，その下段の図から分かるよう に $L_{x}$ と $L_{y}$ は 0 に保たれていない. 角運動量の時間微分はト ルクに等しいから， $\dot{L}_{x}, \dot{L}_{y}$ は重心の床面投影点から ZMP を変 位させる効果を持つ.しかし ZMP のずれは支持脚足裹の範囲 内に留まり，支持脚と床面の接触が保たれることを別途計算に より確認した。一方， $L_{z}$ は 0 に保たれているから Yaw モーメ ント $\left(=\dot{L}_{z}\right)$ は発生しないと期待できる.

この運動パターンを実際の HRP-2 に与えた実験の様子を Fig. 8 に示す。実験ではパターンを再生する際に安定化制御 系（文献 [19] の制御系を改良したもの）を併用した。これは口 ボットのパラメータ誤差等を補償するために関節軌道を微修正: するものであり, 分解運動量制御の軌道に大きな影響を与える ものではない. Fig. 9 はロボットの支持脚足部に内蔵された力 センサで計測した ZMP と 3 軸モーメントである，ZMPの変

†線形倒立振子モードは平地歩行では高さ，定の重心運動を与える。これ をそのまま利用すると遊脚の上下動に呼応して支持脚相中間で腰高さ最 低，两脚支持期に腰高さが最高となる歩行パ夕ーンが生成される。これ は人間の歩行とは逆の腰上下動となって不自然なため腰高さを一定とす る制約を与えた。
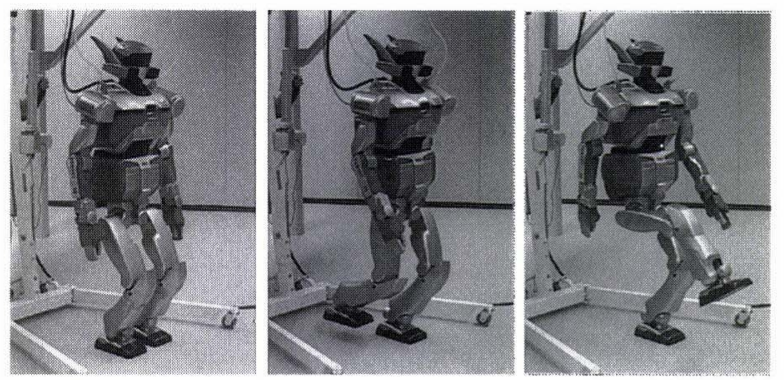

Fig. 8 Kick experiment: $S=\left[\boldsymbol{e}_{1} \boldsymbol{e}_{2} \boldsymbol{e}_{3} \boldsymbol{e}_{6}\right]^{T}$
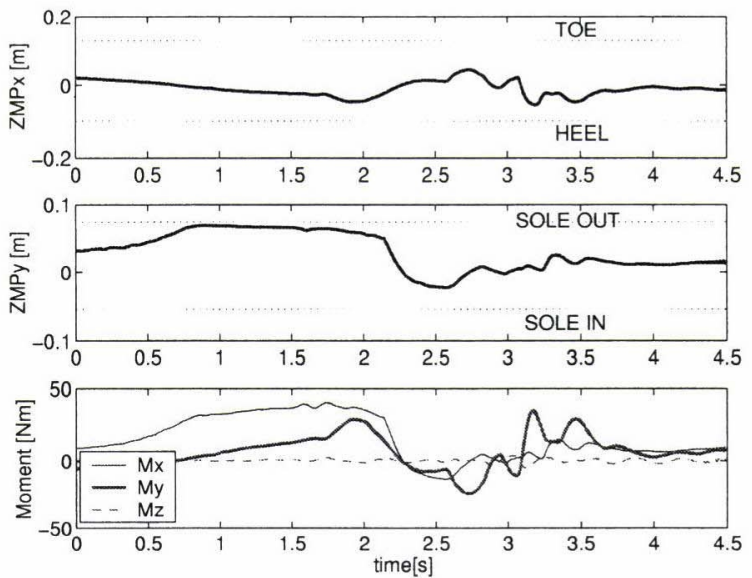

Fig. 9 ZMP and moment at support foot (experiment)

動は, 支持脚足裏の範囲内であり安定した接触が維持されてい ることが分かる. また最下段のグラフは 3 軸モーメントのうち $M_{z}$ が他の成分に比べて小さく保たれていることを示している. $M_{z}$ の変化は $\pm 5[\mathrm{Nm}]$ 以内であり, 分解運動量制御が作り出し た腕の振りと腰の回転により実際にYaw モーメントが補償さ れたことが分かる。

\section{2 歩行動作}

筆者らはロボット全体を一質点の倒立振子として近似したの ち, その解析解に基づいて 2 足歩行パターンを効率よく生成す る三次元線形倒立振子モード [20] を提案している。この際，簡 単のため重心のかわりに腰りンクの軌道を制御して 2 足歩行運 動を生成していたが, 分解運動量制御を用い机ば近似ではなく ロボット全体の重心運動を正確に設定できる。 三次元線形倒立 振子を用いて歩行パターンを生成し，ロボット全体の重心がこ れに追従するように式（28）で目標運動量を設定した。ただし， 腰の上下動については式（29）により一定高さで歩行するよう にした†。ロボット全体を倒立振子のダイナミクスに一致させる ため, 重心回りの角運動量をすべて 0 に設定した場合, Fig. 3 と 同様に胴体が過大な摇動を発生し, 実行可能な歩行動作を得る ことができなかった. そこで, 角運動量 $L_{x}, L_{y}$ の制御は行わな いものとして生成した歩行パターン（一歩 $0.8[\mathrm{~s}]$, 歩幅 $25[\mathrm{~cm}]$ ) の ZMP と腰中心の軌跡老 Fig. 10 に示す (進行方向). ZMP (紐線) は支持領域の範囲内で变化して抢り安定な歩行が可能 なことが分かる。 なお，支持脚交換の直後に ZMP のオーバー シュート (矩印) が発生しているが,これは制御しなかった角 


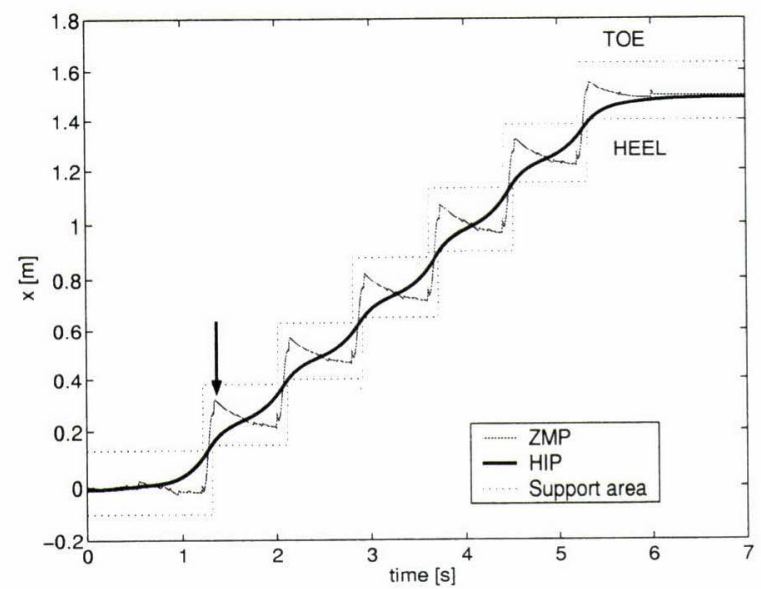

Fig. 10 Hip motion and Zero-moment point (simulation)
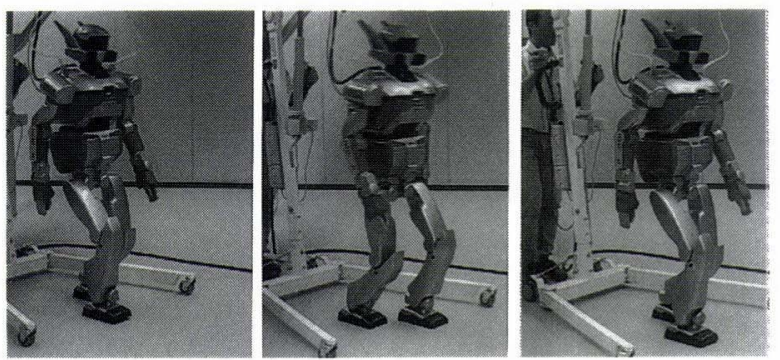

Fig. 11 Walk experiment: $S=\left[\boldsymbol{e}_{1} \boldsymbol{e}_{2} \boldsymbol{e}_{3} \boldsymbol{e}_{6}\right]^{T}$

運動量 $L_{y}$ の影響である.

Fig. 11 に生成された歩行パターンを用いた歩行実験の様子 を示す。この実験もオフライン生成された歩行パターンに前述 の安定化制御系を併用して行った，ZMPのオーバーシュート の影響により多少振動が観察されたが転倒することなく歩行を 実現することができた，写真から $L_{z}$ を 0 に設定することで得 られた自然な腕振りの様子を見ることができる。逆の見方をす ればロボットは腕振りによって $L_{z}=0$ を実現し，接地面で発 生する鉛直軸回りのモーメントを抑制していることになる.

\section{3 計算実行時間について}

分解運動量制御の実装はヒューマノイド用動力学シミュレー 夕 OpenHRP [21] 上に行った. Fig. 3 の計算，すなわち 30 自 由度のロボットに対しすべての運動量要素を指定した場合の軌 道算出に要した時間は単位時間刻み当たり平均 1.59 [ms]（Intel XEON processor $2.8 \mathrm{GHz}$ dual）であった。このうち慣性行列 の計算に要したのが $0.89[\mathrm{~ms}](56 \%)$, 擬似逆行列の計算に要 したのが $0.31[\mathrm{~ms}](19 \%)$ である。なお，慣性行列の計算に関 しては最適化がなされておらず，さらなる高速化が可能である。 本論文で行った実験では $5[\mathrm{~ms}]$ ごとに関節目標值を更新したの で, 適切な高速化を行えば分解運動量制御を実時間の軌道生成 アルゴリズムとして使用できることが分かる.

\section{6. 結}

\section{論}

本論文ではヒューマノイドロボットの動作生成に関して, 指 定された並進運動量と角運動量を実現するように運動を生成す る手法である「分解運動量制御」を提案し，これを用いること
で片脚でのダイナミックなバランス維持と自然な腕振りを伴う 2 足歩行運動を生成できることをシミュレーションと実験によ り示した。

同じ方法を用いて鉛直方向の運動量を制御すれば, 2 足ロボッ

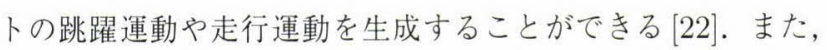
Neo らは両足先に加え両手先にも位置拘束を導入した分解運 動量制御を実時間制御系の一部として実装し, 実際のロボット を用いてバランス維持しつつ作業を行わせる実験に成功してい る [23].

3.3 節で示したように分解運動量制御はヒューマノイドロボッ トだけではなく，宇宙ロボットの制御にも用いることができる。 さらに敷衍すれば，本手法は脚型・車輪型を問わずあらゆる夕イ プの移動ロボットの運動生成に適用できる可能性がある。この 観点からすれば，転がり接触等で発生するノンホロノミック拘 束をどのように取り込み得るかは今後の興味深い課題となろう.

謝 辞 本研究は経済産業省/NEDOの「人間協調・共存型 ロボットシステム」の一環として行われた．プロジェクトの推 進に尽力された多くの方々に心より感謝する。

\section{参 考 文 献}

[1]山口, 木下, 高西, 加藤; “路面形状に偏差のある環境に対する適応 能力を持つ 2 足歩行ロボットの開発”, 日本ロボット学会誌, vol.14, no.4, pp.546-559, 1996.

[2] K. Hirai, M. Hirose, Y. Haikawa and T. Takenaka: "The Development of Honda Humanoid Robot," Proc. of the 1998 ICRA, pp.1321-1326, 1998.

[3] K. Nishiwaki, T. Sugihara, S. Kagami, F. Kanehiro, M. Inaba and H. Inoue: "Design and Development of Research Platform for Perception-Action Integration in Humanoid Robot: H6," Proc. Int. Conference on Intelligent Robots and Systems, pp.1559-1564, 2000.

[4] K .Kaneko, F. Kanehiro, S. Kajita, K. Yokoyama, K. Akachi, T. Kawasaki, S.Ota and T. Isozumi: "Design of Prototype Humanoid Robotics Platform for HRP," Proc. of IROS 2002, 2002.

[5] W.L. Wooten and J.K. Hodgins: "Simulating Leaping, Tumbling, Landing and Balancing Humans," Proc. of 2000 ICRA, pp.656-662, 2000

[6]田宮, 稲葉, 井上：“人間型ロボットの片足立脚動作における全身を 用いた実時間動バランス補償”, 日本ロボット学会誌, vol.17, no.2, pp. 268-274, 1999 .

[7] P. Baerlocher and R. Boulic: "Task-Priority Formulations for the Kinematic Control of Highly Redundant Articulated Structures," Proc. of 1998 IROS, pp.323-329, 1998.

[8] 長阪, 稲葉, 井上：“動力学的動作変換フィルタ群を用いた人間型ロ ボットの全身行動設計”, 第 17 回日本ロボット学会学術講演会子稿 集, pp.1207-1208, 1999.

[9] K. Yamane and Y. Nakamura: "Dynamics Filter - Concept and Implementation of On-Line Motion Generator for Human Figures," Proc. of ICRA2000, pp.699-695, 2000.

[10] 梶田, 金広, 横井, 比留川: “モーメンタム・コントロール:運動量と角 運動量に基づくヒューマノイドロボットの全身運動生成”, 日本ロボッ 卜学会創立 20 周年記念学術講演会予稿集 CD-ROM, 1D 15, 2002.

[11] A. Sano and J. Furusho: "Realization of Natural Dynamic Walking Using The Angular Momentum Information," Proc. of ICRA1990, Cincinnati, 3, pp.1476-1481, 1990.

[12] 水戸部, 益山, 柴田, 山野, 那須：“歩行ロボットの床圧・摩擦力に 基づく ZMP 操作および角運動量制御への応用”, 日本ロボット学会 誌, vol.20, no.5, pp.515-520, 2002.

[13] S. Kajita, K. Yokoi, M. Saigo and K. Tanie: "Balancing a Humanoid Robot Using Backdrive Concerned Torque Control and Direct Angular Momentum Feedback," Proc. of ICRA2001, 
pp.3376-3382, 2001.

[14] 池田, 岩谷, 巣瀬, 美多: “脚式ロボットの走行制御一動物の運動解析 に基づく走行の実現”，システム制御情報学会論文誌，vol.14，no.5, pp.233-243, 2001.

[15] T. Sugihara, Y. Nakamura and H. Inoue: "Realtime Humanoid Motion Generation through ZMP Manipulation based on Inverted Pendulum Control," Proc. of ICRA 2002, pp.1404-1409, 2002.

[16] Y. Umetani and K. Yoshida: "Resolved Motion Rate Control of Space Manipulators with Generalized Jacobian Matrix," IEEE Trans. on Robotics and Automation, vol.5, no.3, pp.303-314, 1989.

[17] H. Inoue, S. Tachi, Y. Nakamura, K. Hirai, N. Ohyu, S. Hirai, K. Tanie, K. Yokoi and H. Hirukawa: "Overview of Humanoid Robotics Project of METI," Proc. of the 32nd ISR, April, 2001.

[18] http://www.kawada.co.jp/ams/promet, 2003.
[19] K. Yokoi, F. Kanehiro, K. Kaneko, K. Fujiwara, S. Kajita and H. Hirukawa: "Experimental Study of Biped Locomotion of Humanoid Robot HRP-1S," Experimental Robotics VIII, STAR 5, pp.75-84, 2003.

[20] S. Kajita, F. Kanehiro, K. Kaneko, et al.: "The 3D Linear Inverted Pendulum Mode: A simple modeling for a biped walking pattern generation," Proc. of 2001 IROS, pp.239-246, 2001

[21] F. Kanehiro, K. Fujiwara, S. Kajita, et al.: "Open Architecture Humanoid Robotics Platform," Proc. of ICRA2002, pp.24-30, 2002.

[22] 長崎, 梶田, 横井, 金子, 谷江：“ヒトサイズの走行ヒューマノイド の実現性の検討”, 日本ロボット学会創立 20 周年記念学術講演会予 稿集 CD-ROM, 1C15, 2002.

[23] E.S. Neo, 横井, 梶田, 谷江：“ヒューマノイドロボットの全身遠隔 操作（モーメンタム・コントロールを用いた全身運動方式）， ロボ ティクス・メカトロニクス講演会 '03 講演論文集, 2 P-1F-F5, 2003.

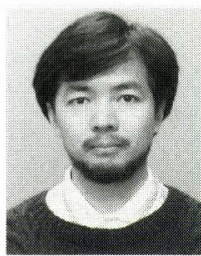

梶田秀司 (Shuuji Kajita)

1961 年 1 月 26 日生. 1985 年東京工業大学大学院 修士課程修了 (制御工学専攻)。同年通产省工業技術 院機械技術研究所に入所. 2 足歩行ロボット等の動 的制御技術の研究に従事. 1996 年 2 月より 1 年間 米国カリフォルニア工科大学客員研究員. 2001 年よ り組織改変に伴い独立行政法人産業技術総合研究所 主任研究員, 現在にいたる. 博士 (工学). 1996 年度計測自動制御学会 論文賞受賞. 計測自動制御学会, IEEE (Robotics and Automation Society) の会員.

(日本ロボット学会正会員)

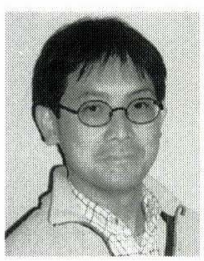

金子健二（Kenji Kaneko）

1965 年 9 月 22 日生. 1990 年慶應義塾大学大学院 理工学研究科電気工学専攻修士課程修了. 同年工業 技術院機械技術研究所に入所. 1995 年 9 月より半 年間米国カーネギーメロン大学客員研究員, 1999 年 9 月より 1 年間仏国 CNRS パリロボット研究所 客員研究員。2001 年より組織改変に伴い独立行政 法人産業技術総合研究所主任研究員, 現在にいたる。博士 (工学). モーションコントロール, マイクロマシン, 遠隔制御, ヒューマノイ ドロボット等の研究に従事. 日本機械学会, 電気学会の各会員.

(日本ロボット学会正会員)

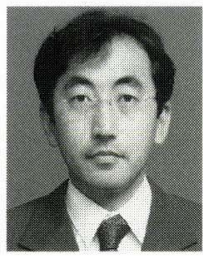

原田研介（Kensuke Harada）

1968 年 9 月 28 日生. 1997 年 3 月京都大学大学 院工学研究科機械工学専攻博士後期課程修了. 博士 (工学)。同年 4 月広島大学工学部助手, 2002 年 4 月独立行政法人産業技術総合研究所研究員. ヒュー マノイドロボット, ロボットハンド, ロボットマニ ピユレータ等, ロボット機構の力学と制御に関する 研究に興味を持つ. IEEE, 計測自動制御学会, 日本機械学会などの 会員.

(日本ロボット学会正会員)

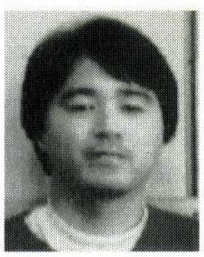

比留川博久 (Hirohisa Hirukawa)

1959 年 1 月 15 日生. 1987 年神戸大学大学院自然 科学研究システム科学専攻博士課程修了. 学術博士. 同年通産省工業技術院電子技術棇合研究所に大所. 1994 1995 年米国スタンフォード大学計算機科学 科客員研究員. 2001 年改組より独立行政法人産業 技術総合研究所知能システム研究部門ヒューマノイ ド研究グループ長、ロボットの動作計画アルゴリズム, ネットワータ ロボティクス, ヒューマノイドロボット等の研究に従事.

(日本ロボット学会正会員)

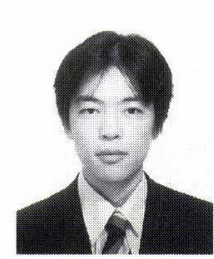

金広文男 (Fumio Kanehiro)

1971 年 7 月 22 日生. 1999 年東京大学大学院工学 系研究科情報工学専攻博士課程修了. 博士 (工学). 1998 年より日本学術振興会特別研究員. 2000 年電 子技術総合研究所入所. 現在産業技術総合研究所知 能システム研究部門研究員.ヒューマノイドロボッ トのシステム構成法，全身行動制御に興味がある。 IEEE, 人工知能学会, 日本ソフトウエア科学会, 情報処理学会の各 会員.

(日本ロボット学会正会員)

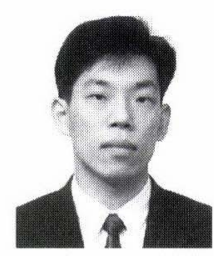

藤原清司（Kiyoshi Fujiwara）

1972 年 4 月 11 日生. 1997 年筑波大学大学院工学 研究科修了. 同年電子技術総合研究所入所. 現在独 立行政法人産業技術総合研究所知能システム部門 ヒューマノイド研究グループ研究員。生体制御, 医 療福祉厂学, マンマシンインタフェース, ヒューマ ノイドロボットなどの研究に従事。

(日本ロボット学会正会員)

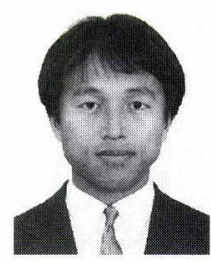

横井一仁 (Kazuhito Yokoi)

1961 年 11 月 11 日生. 1986 年東京工業大学大学 院機械物理工学専攻修了. 博士 (工学). 1986 年工 業技術院機械技術研究所に入所. 1995 - 1996 年久 タンフォード大学客員研究員. 2001 年産業技術総 合研究所知能システム研究部門主任研究員。神奈 川工科大学連携大学院助教授, 東京工業大学非常勤 講師併任. 人間協調 ・共存型ロボットシステムプロジェクトに従事. IEEE, 日本機械学会会員.

(日本ロボット学会正会員) 